\title{
European Youth Work Policy and Young People's Experience of Open Access Youth Work - CORRIGENDUM
}

\author{
JON ORD, MARC CARLETTI, DANIELE MORCIANO, LASSE SIURALA, \\ CHRISTOPHE DANSAC, SUE COOPER, IAN FYFE, KAUR KÖTSI, \\ EEVA SINISALO-JUHA, MARTI TARU AND MANFRED ZENTNER
}

doi:10.1017/So047279421000143, Published by Cambridge University Press, 15 March 2021.

Keywords: youth work; European youth work policy; impact of youth work; experience of young people; friendship \& sociability; corrigendum

The Authors apologise for the following errors in the published paper.

The following references are incorrectly attributed

Council of the European Union (2010), 'Resolution of the Council and of the Representatives of the Governments of the Member States, meeting within the Council, on youth work', Official Journal of the European Union $\mathrm{C}_{327}$, volume 53

Council of the European Union (2018a), 'Engaging, Connecting and Empowering young people: a new EU youth strategy': Official Journal of the European Union $\mathrm{C}_{456} 61$

Council of the European Union (2020) Resolution of the Council and of the Representatives of the Governments of the Member States meeting within the Council on the Framework for establishing a European Youth Work Agenda (2020/C 415/01)

European Union (2018), 'EU Youth Strategy 2019-2027'

\section{Reference}

Ord, J., Carletti, M., Morciano, D., Siurala, L., Dansac, C., Cooper, S., Fyfe, I., Kötsi, K., Sinisalo-Juha, E., Taru, M. and Zentner, M. European Youth Work Policy and Young People's Experience of Open Access Youth Work. Journal of Social Policy. Published by Cambridge University Press, 15 March 2021. doi:10.1017/Soo47279421000143. 